\title{
The effects of adding waste sesame seeds to diets on performance, carcass characteristics, and meat fatty acid composition of Karayaka lambs
}

\author{
İsmail KAYA ${ }^{1, a}$, Bora BÖLÜKBAŞ⿻, ${ }^{1, b, ~}$, Umut AYKUT ${ }^{2, c}$, Mustafa UĞURLU ${ }^{3, d}$, Habip MURUZ ${ }^{1, e}$, \\ Mustafa SALMAN ${ }^{1, \mathrm{f}}$
}

\begin{abstract}
${ }^{1}$ Ondokuz Mayis University, Veterinary Medicine Faculty, Department of Animal Nutrition and Nutritional Diseases, Samsun, Turkey; ${ }^{2}$ Ondokuz Mayıs University, Healthy Sciences Faculty Department of Nutrition and Dietetics, Samsun, Turkey; ${ }^{3}$ Ondokuz Mayis University, Veterinary Medicine Faculty, Department of Animal Breeding and Husbandry, Samsun, Turkey aORCID: 0000-0002-2570-0877; ' $\mathrm{O}$ ORCID: 0000-0002-0732-0192; ' $\mathrm{ORCID:} \mathrm{0000-0002-9072-5560;}$



Corresponding author: bora.bolukbas@omu.edu.tr

Received date: 19.12.2020 - Accepted date: 14.04.2021

\begin{abstract}
This study aims to determine the effects of the inclusion of waste sesame seed (WSS) to concentrate feed on performance, carcass characteristics, and meat fatty acid profile of Karayaka lambs. A total of twenty-three lambs were randomly allocated to a control group (11 lambs, with an average live weight of $23.39 \pm 0.58 \mathrm{~kg}$ ) and an experimental group (12 lambs, with an average live weight $23.55 \pm 0.41 \mathrm{~kg}$ ). Also, each of the group was divided into two subgroups according to their gender. The lambs were fed with isonitrogenous $(17 \% \mathrm{CP})$ and isocaloric $(2650 \mathrm{kcal} / \mathrm{kg} \mathrm{ME})$ concentrate feeds containing either $0 \%$ WSS (control) or $10 \%$ WSS (experimental) for 60 days. Final live weight, average daily weight gain (ADG), feed conversion ratio (FCR), and carcass traits were not affected by diet, although they were higher in males than females $(\mathrm{P}<0.01)$. In addition, males presented a higher percentage of $\mathrm{C} 17: 1, \mathrm{C} 18: 2 \mathrm{n6}, \mathrm{C} 20: 3 \mathrm{n} 6(\mathrm{P}<0.01)$, and polyunsaturated fatty acid $(\mathrm{P}<0.05)$ than females. In conclusion, the addition of WSS to the lamb diet did not increase the concentration of unsaturated fatty acids in meat. However, WSS can be included up to $10 \%$ in concentrate feed of lambs during fattening period without negative effects on performance and carcass yield.
\end{abstract}

Keywords: Fatty acid profile, Karayaka, lamb meat, waste sesame seed.

\section{Atık susam tohumlarının rasyonlara ilavesinin Karayaka kuzularının performans, karkas özellikleri ve et yağ asidi bileşimine etkileri}

Özet: Bu çalışmada, atık susam tohumlarının (WSS) konsantre yemlere ilavesinin Karayaka kuzularının performans, karkas özellikleri ve et yağ asidi profili üzerine etkilerinin belirlenmesi amaçlandı. Toplam yirmi üç kuzu, rastgele bir kontrol (11 kuzu ve ortalama canlı ağırlığı 23,39 $\pm 0,58 \mathrm{~kg}$ ) ve bir deneme grubuna (12 kuzu ve ortalama canlı ağırlığı 23,55 kg $\pm 0,41 \mathrm{~kg}$ ) ayrıldı. Ayrıca, her iki grup da cinsiyetlerine göre iki alt gruba bölündü. Kuzular, WSS içermeyen (kontrol) ve \%10 WSS ilave edilen (deneme grubu) izonitrojenik (\%17 HP) ve izokalorik (2650 kcal/kg ME) konsantre yemlerle 60 gün süresince beslendi. Kuzuların deneme sonu canlı ağırlıkları, günlük canlı ağırlık artışları ve yemden yararlanma oranlarının rasyondan etkilenmediği, ancak bu değerlerin erkek hayvanlarda dişilere göre daha yüksek olduğu saptandı $(\mathrm{P}<0,01)$. Ayrıca, et yağ asidi kompozisyonu bakımından erkek kuzuların dişilere kıyasla daha yüksek oranda C17:1, C18:2 n6, C20:3 n6 $(\mathrm{P}<0,01)$ ve çoklu doymamış yağ asidi içerdiği $(\mathrm{P}<0,05)$ tespit edildi. Sonuç olarak, kuzu rasyonlarına WSS ilavesinin, etteki doymamış yağ asitleri konsantrasyonunu artırmadığı tespit edilmiştir. Bununla birlikte besi dönemindeki kuzuların konsantre yemlerine performans ve karkas verimi üzerinde negatif bir etkiye yol açmaksızın \%10'a kadar WSS dahil edilebileceği kanısına varılmıştır.

Anahtar sözcükler: Karayaka, kuzu eti, susam tohumu atı̆̆ı, yağ asidi profili.

\section{Introduction}

The agriculture sector producing feedstuffs for domestic livestock is confronted with problems such as the consistent supply of raw materials and price fluctuations (25). Researchers usually recommend the use of local agro-industrial by-products to decrease feeding costs. Therefore, the most appropriate local agroindustrial by-products should be utilized in livestock 
feeds, providing they do not adversely affect animal health and are cost-effective in terms of productivity.

Sesame (Sesamum indicum L.) is an oilseed plant that is cultivated primarily for the production of sesame oil, tahini (tehineh). It is used as an ingredient in foods such as halva, sesame bread, java beans, and salads (13). In addition, many by-products are obtained during the processing of sesame seeds and these are used in animal nutrition. Some studies have been conducted with refused and waste sesame seeds (1), sesame oil (18), sesame meal (22), and sesame hull (8) included. Waste sesame seed (WSS) is a by-product obtained during the sorting and sieving processes of sesame seed. It consists mainly of low-quality sesame seeds (e.g., broken or small-sized seeds) and some harvest residues. It is rich in nutritional values and could be used as an alternative feed ingredient for ruminants (1).

Meat is one of the crucial protein sources for human nutrition. Red meat is the most preferred because it best provides the nutrients, such as essential fatty acids, amino acids, minerals, and vitamins, needed for bodily functions and growth (16). However, the fatty acid profile of meat, especially its saturated fatty acid (SFA) composition, is criticized for contributing to cardiovascular diseases, obesity, and diabetes. On the other hand, the unsaturated fatty acids (UFA) in meat are considered important due to their nutritional properties and beneficial effects on human health (11). Therefore, safe, healthy and high-quality red meat production is needed to ensure the health of consumers.

Sesame by-products are used in some countries to enhance the growth performance and carcass characteristics of lambs (22). However, there is scarce information about the effects of waste sesame seed on fatty acid profile of ruminant meat, particularly in lambs (8). Therefore, we aimed to investigate the effects of WSS inclusion in diets on performance, carcass characteristics and the fatty acid profile of lamb meat.

\section{Materials and Methods}

Animals, diets, and experimental design: This study was approved by the Local Ethics Committee of Ondokuz Mayis University for Experimental Animals (Approval number: HADYEK/2018/18). A total of twenty-three lambs with aged 2.5 to 3 months, were randomly divided into a control group (6 males and 5 females) and an experimental group ( 6 males and 6 females). Each group was divided into two subgroups according to their gender ( $2 \times 2$ factorial design). The mean live weight of the control group was $23.39 \mathrm{~kg}( \pm 0.58 \mathrm{~kg})$ and the experimental group was $23.55 \mathrm{~kg}( \pm 0.41 \mathrm{~kg})$. Before starting the trial, the lambs were treated against internal and external parasites, vaccinated against enterotoxaemia and put through two weeks of dietary adaptation. The lambs were fed as group ad libitum with an isonitrogenic $(17 \% \mathrm{CP})$ and isocaloric (2650 kcal/ $\mathrm{kg} \mathrm{ME)} \mathrm{ration} \mathrm{consisting} \mathrm{of} \mathrm{concentrate} \mathrm{(85 \% )}$ and alfalfa hay (15\%) throughout the study. The diets included: control diet without waste sesame seed (WSS) and experimental diet (10\% WSS). The WSS was provided by a sesame seed processing factory that produced tehineh. The ingredients and the chemical composition of experimental diets, forage and WSS are presented in Table 1. During the 60-day intensive fattening period, the amount of diet offered to animals daily was $10 \%$ more than the previous day's consumption.

The chemical composition (dry matter, ash, crude protein, ether extract, and crude cellulose) of the diets were analyzed according to the methodology of the AOAC (6).

Dry matter intake and performance: Dry matter intake (DMI) was determined by weighing the amounts of feeds offered and refusals daily. The animals were weighed individually at the start of the experiment (day 0) and every 30 days during the experimental period. Average daily gain, average feed intake and feed conversion ratio were calculated.

Slaughter and carcass traits: The final weight of the lambs was determined at the end of the fattening period. Animals were slaughtered after being deprived of feed for $16 \mathrm{~h}$ with having free access to water (28). Hot and cold dressing percentages were calculated according to the slaughter weight of the lambs. The carcasses were kept at $4{ }^{\circ} \mathrm{C}$ for $24 \mathrm{~h}$, and then the cold carcass weights were recorded. Following that, the cold carcass percentages and chilling losses were calculated.

Fatty acid composition of WSS and meat samples: $10 \mathrm{~g}$ of WSS and $10 \mathrm{~g}$ of meat samples from each animal were added to a chloroform/methanol solution $(2: 1 \mathrm{v} / \mathrm{v})$ and the samples were homogenized. Ten milliliters of 10 $\mathrm{mM} \mathrm{CaCI}{ }_{2}$ was added to the homogenate, and the mixture was stirred vigorously for 30 seconds. The mixture was centrifuged at $2000 \mathrm{xg}$ for 15 minutes. The chloroform phase was transferred to a flask and evoparated by a vacuum evaporator. The fat mass was then used for the determination of total fatty acids composition (10). The content of major fatty acids in the lipid mixture was determined after methylation (5) by gas chromatographymass spectrophotometry (GC-MS) (Shimadzu model of QP2010 Plus, Shimadzu Corporation, Kyoto, Japan), using an Agilent HP-88 column (60 m x $0.25 \mathrm{~mm}$ I.D., $0.20 \mu \mathrm{m}$ ) (Agilent, USA). The temperatures of the injector port and detector were maintained at $250{ }^{\circ} \mathrm{C}$. The injected volume was $1.0 \mu \mathrm{L}$ and the carrier gas was helium at a pressure of $200 \mathrm{kPa}$ (split ratio 1:100). The temperature of the column was maintained at $90^{\circ} \mathrm{C}$ for $7 \mathrm{~min}$, then raised to $240{ }^{\circ} \mathrm{C}$ at $5{ }^{\circ} \mathrm{C} / \mathrm{min}$ and finally held at $240{ }^{\circ} \mathrm{C}$ for 10 min. The main fatty acids were identified by comparing retention times with the original standards (Supelco 37 
Components FAME Mixture, Cat. No. 18919-1AMP, Bellefonte PA, USA) and are reported as a proportion (\%) of the total fatty acids recorded (5).

Statistical analyses: The data were analyzed with SPSS (IBM Inc., USA, version 21). The KolmogorovSmirnov Test was used to check for normal distribution. The homogeneity of variances were evaluated with the Levene Test. The performance parameters, carcass traits and fatty acid profile of the diet (control and treatment) and gender (male and female) groups and their interactions were compared with General Linear Model (GLM). A level of $\mathrm{P}<0.05$ was accepted as statistically significant.

\section{Results}

Feed ingredients and the chemical composition of concentrates, forage and WSS are shown in Table 1. In addition, the fatty acid profile of the WSS used in the experimental concentrate was determined to be C14:0 (0.118\%), C16:0 (12.77\%), C17:0 (0.049\%), 17:1 (0.077\%), C18:0 (22.22\%), C18:1 (24.97\%), C18:2 (38.21\%), C18:3 (1.07\%), C20:0 (0.096\%), C20:1 (0.026\%), 20:2 (0.096\%) and 20:3 (0.072\%).

Data on average daily weight gain (ADG) and final weight are shown in Table 2. Dry matter intake (DMI) and feed conversion ratio (FCR) are demonstrated in Table 3. DMI and FCR were not available for individual animals due to group feeding. However, calculated values showed that feed intakes of lambs in all groups were similar and ranged from 1253 to $1283 \mathrm{~g}$. Final live weights, ADG and
FCR were unaffected $(\mathrm{P}>0.05)$ by diet but were higher $(\mathrm{P}<0.01)$ for males than females.

Carcass characteristics for all groups are presented in Table 2. Mean values for the carcass characteristics were similar for the control and experimental. In terms of gender groups, the values for the carcass characteristics of male lambs, except for cold dressing percentage, were tend to be higher than those of female lambs. The mean final $\mathrm{pH}(24 \mathrm{~h})$ in the musculus longissimus dorsi was 5.77 and 5.8 for the control and treatment groups respectively, and 5.83 and 5.74 for males and females respectively.

The fatty acid profiles for the groups are presented in Table 4. No significant differences were generally observed for the fatty acid profile of meat from the control and experimental groups ( $\mathrm{P}>0.05)$. In both diet and gender groups, the percentages for the fatty acids C16:0 (21.4822.22\%), C18:0 (15.78-17.25\%), and C18:1 (40.44$41.77 \%$ ) were by far the highest. The mean fatty acid percentages in the male lamb meats were generally higher than those of female lamb meats. The males presented a higher percentage of C17:1 (heptadecanoic), C18:2 n6 (linoleic), 20:3 n6 (eicosadienoic) $(\mathrm{P}<0.01)$, and total polyunsaturated fatty acid $(\mathrm{P}<0.05)$ than females. In addition, significant differences were found between the genders with regard to some saturated fatty acid (C10:0, C15:0, C17:0) $(\mathrm{P}<0.05)$ and monounsaturated fatty acid (MUFA) concentrations $(\mathrm{C} 17: 1)(\mathrm{P}<0.01)$. However, the overall SFA and MUFA percentages were unaffected by diet or gender.

Table 1. Feed ingredients and the chemical composition of concentrates, forage, and WSS.

\begin{tabular}{|c|c|c|c|c|}
\hline Ingredients, \% & Control & Experimental & Alfalfa & WSS \\
\hline Barley & 35.00 & 40.00 & & \\
\hline Corn & 25.50 & 8.50 & & \\
\hline Sunflower meal & 29.00 & 21.00 & & \\
\hline Wheat Bran & 1.70 & 11.70 & & \\
\hline Waste sesame seed & - & 10.00 & & \\
\hline Molasses (sugar beet) & 6.00 & 6.00 & & \\
\hline Salt & 0.70 & 0.70 & & \\
\hline Limestone & 1.50 & 1.50 & & \\
\hline $\mathrm{MCP}^{1}$ & 0.50 & 0.50 & & \\
\hline Premix ${ }^{2}$ & 0.10 & 0.10 & & \\
\hline \multicolumn{5}{|c|}{ Chemical composition, \% DM } \\
\hline Dry matter & 89.63 & 89.8 & 90.12 & 94.47 \\
\hline Organic matter & 81.32 & 81.6 & 80.73 & 79.80 \\
\hline Crude Protein & 17.03 & 17.64 & 17.40 & 15.55 \\
\hline Ether extract & 3.04 & 5.12 & 1.34 & 33.37 \\
\hline Crude Cellulose & 8.46 & 7.99 & 29.50 & 14.6 \\
\hline $\mathrm{ME}^{3}, \mathrm{kcal} / \mathrm{kg}$ & 2657 & 2658 & 2258 & 3450 \\
\hline
\end{tabular}

${ }^{1}$ : Monocalcium phosphate, ${ }^{2}$ : Composition (per $1 \mathrm{~kg}$ of the mixture): Vit A $8000000 \mathrm{IU}$, Vit $\mathrm{D}_{3} 2000000$, Vit E $20000 \mathrm{mg}, \mathrm{Mn} 50000$ mg, Zn 50000 mg, Cu 10000 mg, Co 150 mg, I 800 mg, Se 150 mg, CaCO 310000 mg, Cibus 32 Vanilla aroma 200000 mg. (Icon Agro Novimix Ruminant VM01+Aroma), ${ }^{3}$ ME: Metabolizable energy; calculated (20, 27). 
Table 2. Effects of diet and gender of lambs on performance and some carcass traits.

\begin{tabular}{|c|c|c|c|c|c|c|c|c|}
\hline \multirow[t]{2}{*}{ Item } & \multicolumn{2}{|c|}{ Diet } & \multicolumn{2}{|c|}{ Gender } & \multirow[t]{2}{*}{ SEM } & \multicolumn{3}{|c|}{$P$ value } \\
\hline & Control & Treatment & Male & Female & & D & $\mathbf{G}$ & $D * G$ \\
\hline Initial weight & 23.47 & 23.38 & 22.91 & 23.93 & 0.36 & NS & NS & NS \\
\hline Final weight & 32.32 & 32.59 & 34.66 & 30.25 & 0.57 & NS & $* *$ & NS \\
\hline $\mathrm{ADG}(\mathrm{kg})$ & 0.139 & 0.147 & 0.190 & 0.102 & 0.008 & NS & $* * *$ & NS \\
\hline Slaughter weight $(\mathrm{kg})$ & 31.80 & 32.19 & 34.30 & 29.68 & 0.57 & NS & $* * *$ & NS \\
\hline HCW (kg) & 15.40 & 15.30 & 15.97 & 14.74 & 0.36 & NS & NS & NS \\
\hline $\operatorname{HDP}(\%)$ & 48.22 & 48.33 & 47.20 & 49.36 & 0.46 & NS & $*$ & NS \\
\hline CCW (kg) & 14.99 & 14.85 & 15.51 & 14.33 & 0.36 & NS & NS & NS \\
\hline $\operatorname{CDP}(\%)$ & 45.65 & 46.32 & 46.04 & 45.92 & 0.90 & NS & NS & NS \\
\hline Chilling loss (\%) & 2.68 & 3.02 & 2.91 & 2.78 & 0.18 & NS & NS & NS \\
\hline pH0 & 6.22 & 6.23 & 6.32 & 6.14 & 0.07 & NS & NS & NS \\
\hline $\mathrm{pH} 24$ & 5.77 & 5.8 & 5.83 & 5.74 & 0.02 & NS & NS & NS \\
\hline
\end{tabular}

D: Diet, G: Gender, ADG: Avarage daily gain, HCW: Hot carcass weight, HDP: Hot dressing percentage, CCW: Cold carcass weight, CDP: Cold dressing percentage, *: $\mathrm{P}<0.05$, **: $\mathrm{P}<0.01$, ***: $\mathrm{P}<0.001$, NS: non-significant.

Table 3. The mean feed consumption and feed conversion ratio of lambs (Dry matter basis).

\begin{tabular}{|c|c|c|c|c|}
\hline \multirow{2}{*}{ Item } & \multicolumn{2}{|c|}{ Control } & \multicolumn{2}{|c|}{ Treatment } \\
\hline & Male & Female & Male & Female \\
\hline Concentrate intake, $\mathrm{g} /$ day & 1069 & 993 & 1033 & 978 \\
\hline Forage intake, g /day & 214 & 270 & 238 & 275 \\
\hline Total dry matter intake, $\mathrm{g} /$ day & 1283 & 1263 & 1272 & 1253 \\
\hline Feed convertion ratio & 6.66 & 12.31 & 6.61 & 10.81 \\
\hline
\end{tabular}

Table 4. Effects of diet and gender of lambs on meat fatty acid profile (\%).

\begin{tabular}{|c|c|c|c|c|c|c|c|c|}
\hline \multirow[b]{2}{*}{ Item } & \multicolumn{2}{|c|}{ Diet } & \multicolumn{2}{|c|}{ Gender } & \multirow[t]{2}{*}{ SEM } & \multicolumn{3}{|c|}{$P$ value } \\
\hline & Control & Treatment & Male & Female & & D & G & $D * G$ \\
\hline C10:0 & 0.17 & 0.15 & 0.17 & 0.15 & 0.01 & NS & $*$ & NS \\
\hline C12:0 & 0.21 & 0.16 & 0.20 & 0.17 & 0.01 & NS & NS & $*$ \\
\hline C14:0 & 2.86 & 2.50 & 2.72 & 2.64 & 0.11 & NS & NS & $*$ \\
\hline C14:1 & 0.25 & 0.21 & 0.23 & 0.23 & 0.01 & $*$ & NS & $*$ \\
\hline C15:0 & 0.46 & 0.42 & 0.47 & 0.41 & 0.01 & NS & $*$ & $* *$ \\
\hline C15:1 & 0.14 & 0.12 & 0.14 & 0.13 & 0.01 & $*$ & NS & $*$ \\
\hline C16:0 & 22.22 & 21.48 & 21.89 & 21.81 & 0.18 & NS & NS & NS \\
\hline C16:1 & 1.39 & 1.10 & 1.28 & 1.21 & 0.04 & $* *$ & NS & NS \\
\hline C17:0 & 1.27 & 1.13 & 1.30 & 1.09 & 0.04 & NS & $*$ & NS \\
\hline C17:1 & 0.77 & 0.61 & 0.77 & 0.62 & 0.02 & $* *$ & $* *$ & NS \\
\hline C18:0 & 15.78 & 17.56 & 16.09 & 17.25 & 0.43 & NS & NS & NS \\
\hline C18:1 & 41.77 & 40.44 & 40.76 & 41.45 & 0.42 & NS & NS & $*$ \\
\hline C18:2 n6 & 4.78 & 4.54 & 5.17 & 4.01 & 0.16 & NS & $* *$ & NS \\
\hline $\mathrm{C} 18: 3 \mathrm{n} 3$ & 1.17 & 1.38 & 1.32 & 1.23 & 0.08 & NS & NS & NS \\
\hline C20:0 & 0.94 & 0.72 & 0.75 & 0.98 & 0.04 & $*$ & NS & NS \\
\hline C20:3 n6 & 0.74 & 0.77 & 0.86 & 0.65 & 0.03 & NS & $* *$ & $*$ \\
\hline C20:3 n3 & 0.26 & 0.40 & 0.36 & 0.31 & 0.04 & NS & NS & NS \\
\hline C20:4 n6 & 0.20 & 0.38 & 0.33 & 0.25 & 0.04 & NS & NS & NS \\
\hline $\mathrm{C} 22: 3$ & 0.24 & 0.26 & 0.29 & 0.22 & 0.02 & NS & NS & NS \\
\hline $\mathrm{C} 24: 0$ & 0.11 & 0.19 & 0.16 & 0.14 & 0.01 & $* *$ & NS & NS \\
\hline $\mathrm{C} 24: 1$ & 0.25 & 0.27 & 0.24 & 0.28 & 0.02 & NS & NS & NS \\
\hline SFA & 44.05 & 44.35 & 43.79 & 44.6 & 0.49 & NS & NS & NS \\
\hline MUFA & 44.84 & 43.06 & 43.74 & 44.17 & 0.44 & NS & NS & NS \\
\hline PUFA & 7.17 & 7.48 & 8.05 & 6.60 & 0.24 & NS & $*$ & NS \\
\hline
\end{tabular}

D: Diet, G: Gender, SFA: Saturated fatty acid, MUFA: Monounsaturated fatty acid, PUFA: Polyunsaturated fatty acid, *: P<0.05, **: $\mathrm{P}<0.01$, ***: $\mathrm{P}<0.001$, NS: non-significant. 


\section{Discussion and Conclusion}

The effects of adding fat to the ruminant diets depend on the amount and structural characteristics of the lipid source (12). Oils with high UFA content added to ruminant diets may cause adverse effects on dry matter intake due to their toxic effects on cellulolytic bacteria (21). In our experiment, the addition of WSS with a high UFA content to the diet did not affect the total dry matter intake. These results can be attributed to two factors: the dietary fat content $(51.3 \mathrm{~g} \mathrm{EE} / \mathrm{kg} \mathrm{DM})$ and the form of WSS (oilseed). The DMI reduction by lipid supplementation is observed generally in animals fed diets with a higher lipid content ( $>60 \mathrm{~g} \mathrm{EE} / \mathrm{kg} \mathrm{DM})$ than used in our study (19). In rumen, oilseeds have less direct contact with rumen microorganisms and tend to release its fatty acid content slower than free oils. Therefore, fat supplementation in the form of oilseed has less detrimental effects on DM intake than free oils (12).

Final live weights, average daily weight gain, and feed conversion ratio were not affected by diet. Similar findings have also been reported for fattening lamb fed with sesame oil (18) or other lipid sources (23). The fact that the diets were isoenergetic and isonitrogenous may explain the absence of significant differences in performance. However, growth performance was affected by gender. Although dry matter consumption was similar in all groups, the lower fattening performance was observed in female groups regardless of diet. These results are consistent with other studies in which female lambs showed lower growth performance than males (14). This may related to the physiological and hormonal difference between male and female lambs (14). On the other hand, the ADG for males and females of Karayaka lambs in this experiment was lower compared to other studies $(24,29)$.

The lambs in all groups were fed with isonitrogenous and isocaloric diets. However, the ether extract content of the experimental diet was $2.08 \%$ higher than the control diet. Haddad and Younis (19) reported that adding fats to the diet of fattening lambs did not modify growth performance or carcass characteristics. Another study also reported no differences in growth performance and carcass characteristics when lambs received up to $6 \%$ of supplementary fat (9). Therefore, the absence in the present study of significant differences concerning carcass characteristics may be related to the same energy:protein ratio of the diets.

The slaughter weight of male lambs was significantly higher than the females $(12.72 \% ; \mathrm{P}<0.001)$. This difference between genders can be explained by the presence of the muscle-building, anabolic hormone testosterone in males (14). The hot and cold carcass weights were unaffected by diet and gender $(\mathrm{P}>0.05)$. However, overall, the hot and cold carcass weight of male lambs was higher than that of female lambs but not significantly $(\mathrm{P}>0.05)$. Contrary to this situation, the hot carcass percentage of male lambs was lower than that of female lambs. The higher carcass percentage of female lambs can be explained by the lower percentage of the non-carcass component of female lambs. These results are in line with hot carcass characteristics; the chilling loss was $2.78 \%$ and $2.91 \%$ for the male and female lambs, respectively. However, these chilling losses were higher than the reported optimum range of $1 \%$ to $2 \%$ (2).

A carcass $\mathrm{pH}$ value of greater than 5.8 at $24 \mathrm{~h}$ postmortem is regarded as undesirable (26). In the present study, the mean $\mathrm{pH}$ values at $24 \mathrm{~h}$ postmortem were 5.73 and 5.87 for the diet and gender groups, respectively. The $\mathrm{pH}$ values obtained from the current study were within the acceptable range.

Sheep meat has been reported to contain mainly C14:0 (myristic acid), C16:0 (palmitic acid), C18:0 (stearic acid), and C18:1 (oleic acid) (17). However, the composition of the diet was reported to affect on body fat stores and the fatty acid profile of sheep meat (23). A study that investigated the effect of different diets on the fatty acid profile reported that oleic acid (C18:1), palmitic acid (C16:0) and stearic acid (C18:0) predominated in the longissimus thoracis muscle (51). The fatty acid profile of the meat obtained at the end of the experiment, namely C14:0 (2.50-2.86\%), C16:0 (21.8-22.2\%), C18:0 (15.7$17.2 \%), \mathrm{C} 18: 1$ (40.4-41.7\%) and $\mathrm{C} 18: 2$ (4.0-4.7\%), was comparable with the fatty acid profile generally seen in meat of lambs (18). Additionally, SFA and MUFA levels predominated and polyunsaturated fatty acid (PUFA) levels were low. Therefore, it appears that PUFA in waste sesame seeds oil is dehydrogenated and broken down to short-chain fatty acids by microbial lipases which are absorbed, transferred in the blood, and then reassembled in the tissues as long-chain fatty and that only a small proportion is transferred to the muscle.

In the current study, the fatty acid profiles of male lambs from the different feeding groups were similar, whereas the means for C17:1, C18:2 n6 and C20:3 n6 and MUFA were all significantly lower $(\mathrm{P}<0.05)$ than for the same characteristics of the females. It has been reported that a fatty carcass is obtained from female lambs that have been fattened (3). The Karayaka sheep breed is lean and long-tailed, and the accumulation of intramuscular fat contributes to fatness in the carcass. Moreover, the PUFA proportion decreases with increasing intramuscular fat accumulation in comparison to the SFA ratio (15). The high proportion of fat in the ration when the WSS was added may have increased the carcass fatness in the female group. Therefore, the low amount of PUFA in the muscle tissue of female lambs can be explained by the increase in carcass fatness of female lambs.

In one study from Turkey, the meat quality characteristics of Karayaka lambs were determined at 
different slaughter weights after they were fed with lentil straw with high fiber content in addition to concentrated feed. SFAs of $48.94 \%$ and $48.58 \%$ respectively, MUFAs of $42.66 \%$ and $44.41 \%$ respectively, and PUFAs of $7.77 \%$ and $6.98 \%$ respectively, were determined for the fatty acid profile of meat of lambs of $30 \mathrm{~kg}$ and $35 \mathrm{~kg}$ slaughter weight, respectively (4). In the present study, alfalfa hay was used as forage, and it was determined that the ranges of SFA, MUFA, and PUFA were $43.7 \%$ to $44.6 \%, 43 \%$ to $44.84 \%$, and $6.6 \%$ to $8.05 \%$, respectively, in the fatty acid profile of the lambs. It has been reported that rumen $\mathrm{pH}$ may increase when rations have high fiber content and that this situation can change the fatty acid profile (7). Therefore, the difference between the SFA profiles of lambs of the same breed and same body weight in different studies may be related to the use of diets with different fiber content level.

The proportion of PUFA in waste sesame seeds was approximately $40 \%$. Despite that, the saturated fat percentage was also high. Also, the MUFA level in the fatty acid profile of the obtained lamb meats was high but the level of PUFA level was low. These results are comparable with the general fatty acid profile seen in lamb meat. Also, the mean slaughter weight of the experimental group was higher than that of both genders in the control group, and for the control and experimental groups, the carcass percentage of female lambs was higher than that of male lambs.

Overall, even though the waste sesame seed had a high percentage of UFA, it did not significantly change the fatty acid profile of the lamb meats. However, the use of waste sesame seed in combination with an additive that prevents the rumen biohydrogenation of unsaturated fatty acids would be a worthwhile follow-up study.

In conclusion, WSS may not always be effective as a nutritional strategy for increasing UFA percentage in meat. However, it can be included up to $10 \%$ in the concentrate feed of Karayaka lambs during fattening periods with no negative effects on performance and carcass yield.

\section{Acknowledgements}

The authors thank ETB Agricultural Products Company for supplying the concentrate feeds and WSS for our research.

\section{Financial Support}

This study was supported by the ETB Agricultural Products Company.

\section{Ethical Statement}

The procedures and protocols used in this experiment were approved by the Local Ethics Committee of Ondokuz
Mayis University for Experimental Animals (Approval number: HADYEK/2018/18).

\section{Conflict of Interest}

The authors declared that there is no conflict of interest.

\section{References}

1. Abdel-Gawad A, Behery H, El-Emam G, et al (2017): Effect of refused sesame seeds for manufacturing supplement on reproductive and productive performance of dairy goats. Egyptian J Sheep Goat Sci, 12, 119-135.

2. Akçapınar H (2000): Koyun yetiştiriciliği. İsmat Maatbacılık, Ankara.

3. Akçapınar H, Özbeyaz C (1999): Hayvan yetiştiriciliği temel bilgileri. Kariyer Matbaacılık Ltd. Şti., Ankara.

4. Aksoy Y, Ulutas Z (2016): Meat production traits of local Karayaka sheep in Turkey 1. The meat quality characteristic of lambs. Ital J Food Sci, 28, 131-138.

5. Animal I, Fats V (1978): Oils-Preparation of Methyl Esters of Fatty Acids (Method ISO 5509). Geneva: International Organization for Standardization, Routledge.

6. AOAC (2000): Official Methods of Analysis of AOAC International. Association of Official Analytical Chemists. Maryland, USA.

7. Bauman DE, Griinari JM (2003): Nutritional regulation of milk fat synthesis. Annu Rev Nutr, 23, 203-227.

8. Bonos E, Kargopoulos A, Basdagianni Z, et al (2017): Dietary sesame seed hulls utilization on lamb performance, lipid oxidation and fatty acids composition of the meat. Anim Husb Dairy Vet Sci, 1, 1-5.

9. Castro T, Manso T, Mantecón A, et al (2005): Fatty acid composition and carcass characteristics of growing lambs fed diets containing palm oil supplements. Meat Sci, 69, 757-764.

10. Classics Bligh E, Dyer W (1959): A rapid method of total lipid extraction and purification. Can J Biochem Physiol, 37, 911-917.

11. Corpet DE (2011): Red meat and colon cancer: should we become vegetarians, or can we make meat safer? Meat Sci, 89, 310-316.

12. Doreau M, Chilliard Y (1997): Digestion and metabolism of dietary fat in farm animals. Br J Nutr, 78, 15-35.

13. Elleuch M, Besbes S, Roiseux O, et al (2007): Quality characteristics of sesame seeds and by-products. Food Chem, 103, 641-650.

14. Facciolongo A, Lestingi A, Colonna M, et al (2018): Effect of diet lipid source (linseed vs. soybean) and gender on performance, meat quality and intramuscular fatty acid composition in fattening lambs. Small Ruminant Res, 159, 11-17.

15. Fisher A, Enser M, Richardson R, et al (2000): Fatty acid composition and eating quality of lamb types derived from four diverse breed $\times$ production systems. Meat Sci, 55, 141147.

16. Font-i-Furnols M, Guerrero L (2014): Consumer preference, behavior and perception about meat and meat products: An overview. Meat Sci, 98, 361-371.

17. Forrest JC, Aberle ED, Hedrick HB, et al (1975): Principles of meat science. WH Freeman and Co.,UK. 
18. Ghafari H, Rezaeian M, Sharifi S, et al (2016): Effects of dietary sesame oil on growth performance and fatty acid composition of muscle and tail fat in fattening Chaal lambs. Anim Feed Sci Technol, 220, 216-225.

19. Haddad S, Younis H (2004): The effect of adding ruminally protected fat in fattening diets on nutrient intake, digestibility and growth performance of Awassi lambs. Anim Feed Sci Technol, 113, 61-69.

20. Kirchgessner M, Kellner R (1977): Zur Schätzung der umsetzbaren Energie von Grün-und Rauhfutter mit einfachen Kenndaten 1. Z Tierphysiol Tierernahr Futtermittelkd, 38, 297-301.

21. Maia MR, Chaudhary LC, Figueres L, et al (2007): Metabolism of polyunsaturated fatty acids and their toxicity to the microflora of the rumen. Anton Leeuw, 91, 303-314.

22. Obeidat B, Abdullah A, Mahmoud K, et al (2009): Effects of feeding sesame meal on growth performance, nutrient digestibility, and carcass characteristics of Awassi lambs. Small Ruminant Res, 82, 13-17.

23. Peng Y, Brown M, Wu J, et al (2010): Different oilseed supplements alter fatty acid composition of different adipose tissues of adult ewes. Meat Sci, 85, 542-549.
24. Sen U, Sirin E, Ulutas Z, et al (2011): Fattening performance, slaughter, carcass and meat quality traits of Karayaka lambs. Trop Anim Health Prod, 43, 409-416.

25. Stillman R, Haley MM, Mathews Jr KH (2009): Grain prices impact entire livestock production cycle. Econ Res Service, 7, 24-28.

26. Tejeda JF, Peña RE, Andrés AI (2008): Effect of live weight and sex on physico-chemical and sensorial characteristics of Merino lamb meat. Meat Sci, 80, 10611067.

27. TSE (1991): Hayvan Yemleri-Metabolik (Çevrilebilir) Enerji Tayini (Kimyasal Metot). Türk Standartları Enstitüsü, Ankara.

28. TSE (1987): Butcher Animals-Rules for Slaugtering and Carcass Preparation. Türk Standartları Enstitüsü, Ankara.

29. Yıldırım A, Ulutaş Z, Ocak N, et al (2013): Effects of birth weight and feeding system on fattening performance and feeding behaviour of Karayaka male lambs. Ital J Anim Sci, 12, 89-96. 